\title{
Fast conventional Fmoc solid-phase peptide synthesis with HCTU
}

\author{
CHRISTINA A. HOOD, GERMAN FUENTES, HIRENDRA PATEL, KAREN PAGE, MAHENDRA MENAKURU and \\ JAE H. PARK* \\ Department of Chemistry, Protein Technologies Inc., Tucson, Arizona, 4675 South Coach Drive, Tucson, Arizona, 85714, USA \\ Received 28 June 2007; Revised 18 July 2007; Accepted 23 July 2007
}

\begin{abstract}
H-Benzotriazolium 1-[bis(dimethyl-amino)methylene]-5-chloro-hexafluorophosphate (1-),3-oxide (HCTU) is a nontoxic, nonirritating and noncorrosive coupling reagent. Seven biologically active peptides (GHRP-6, ${ }^{65-74}$ ACP, oxytocin, G-LHRH, Cpeptide, hAmylin ${ }_{1-37}$, and $\beta$-amyloid - $_{1-42}$ ) were synthesized with reaction times reduced to deprotection times of 3 min or less and coupling times of $5 \mathrm{~min}$ or less using HCTU as the coupling reagent. Expensive coupling reagents or special techniques were not used. Total peptide synthesis times were dramatically reduced by as much as $42.5 \mathrm{~h}$ (1.8 days) without reducing the crude peptide purities. It was shown that HCTU can be used as an affordable, efficient coupling reagent for fast Fmoc solid-phase peptide synthesis. Copyright (c) 2007 European Peptide Society and John Wiley \& Sons, Ltd.
\end{abstract}

Keywords: HCTU; fast Fmoc SPPS; human amylin (1-37); oxytocin; $\beta$-amyloid

\section{INTRODUCTION}

The ability to assemble peptides faster is highly desirable and has several benefits, including identifying difficult couplings in target sequences as well as increasing the production of small complex peptides, protein mutants and peptide segments used in ligation methods for the construction of small proteins [1].

Fmoc conventional solid-phase peptide synthesis (SPPS) is a very practical method used worldwide for the synthesis of peptides in pharmaceutical companies, active pharmaceutical ingredient (API) manufacturers, university research laboratories and custom peptide manufacturers. Most conventional methods today use extended reaction times to achieve high-purity crude peptides at high yields. Typically, Fmoc protecting groups are removed for $10-30$ min with $20 \%$ piperidine in dimethlyformamide (DMF), and Fmoc-protected amino acids are coupled for 20 min to over an hour to the free amines attached to the solid support, which may result in cycle times of up to $2 \mathrm{~h}$, depending on the choice of chemistry and the synthetic protocol followed.

Over the years, methods to accelerate SPPS have been proposed, which mostly focus on the coupling step. In a kinetic study of the coupling reaction by Hetnarski and Merrifield, it was found that diffusion was not the rate-limiting step for the coupling reaction [1]. Rather, as Miranda and Alewood report, the rate of amino acid acylation is heavily dependent on the properties of the coupling reagents [2]. There have been a few studies on fast conventional SPPS using different coupling

\footnotetext{
* Correspondence to: Jae H. Park, Department of Chemistry, Protein Technologies Inc., Tucson, Arizona, 4675 South Coach Drive, Tucson, Arizona, 85714, USA; e-mail: info@peptideinstruments.com
}

reagents. In 1990, one manufacturer of automated synthesizers illustrated FastMoc chemistry using HBTU

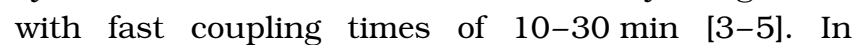
1993, the coupling agent $O$-(7-azabenzotriazole-1yl)- $N, N, N^{\prime} N^{\prime}$-tetramethyluronium hexafluorophosphate (HATU) was introduced [6], and 4 years later, Kent and Alewood et al. reported on an accelerated peptide synthesis with coupling times of 1-2 min using Boc chemistry and HATU [7]. While HATU has also been used as a coupling reagent with Fmoc chemistry $[8,9]$, to our knowledge coupling times less than 15 min were not attempted.

Despite its efficiency, HATU has not enjoyed widespread general use owing to its high cost (The price for $25 \mathrm{~g}$ of coupling reagents as of June 2007 from Novabiochem. HATU: \$340, HBTU: \$55, BOP: \$60, TBTU: \$60, HCTU: \$80, PyBOP: \$112 and ByBroP: $\$ 248$.). Typically, it is reserved only for use in difficult coupling reactions. In 2002, the 6-Cl-HOBt-based coupling reagent $1 \mathrm{H}$-benzotriazolium 1-[bis(dimethylamino)methylene]-5-chloro-hexa-fluorophosphate (1-), 3-oxide (HCTU) was introduced, and found to be nontoxic, stable in DMF and close in efficiency to HATU, but commercially available at the cost of HBTU [10-13]. Internal studies conducted at Protein Technologies, Inc. also investigated the coupling efficiency of HCTU. The 65-74 fragment of the Acyl Carrier Protein $\left({ }^{65-74} \mathrm{ACP}\right)$, (H-VQAAIDYING-OH) was synthesized with various coupling reagents such as HBTU, HATU, HCTU, PyBOP and TBTU. The results showed that HCTU was as effective as HATU, and HCTU gave higher purity peptides than HBTU, PyBOP and TBTU (data not shown). A phosphorylated peptide (H-CRRKGpSQKVS- $\mathrm{NH}_{2}$ ) was also synthesized with HBTU and HCTU to compare 
coupling efficiency. The phosphorylated peptide coupled with HCTU gave a better crude purity than the phosphorylated peptide coupled with HBTU (data not shown).

However, to the best of our knowledge, no study to date has determined the minimum coupling time of HCTU with Fmoc chemistry. In this study, we selected seven biologically active peptides with a broad range of properties including long and short peptides, as well as peptides containing D-amino acids or pseudoproline dipeptides that had been synthesized in our lab using HCTU and long, conservative synthesis times. We then resynthesized these seven peptides using HCTU and short reaction times, and compared the crude purities to evaluate the utility of HCTU as an affordable, highly efficient coupling reagent for fast SPPS.

\section{MATERIALS AND METHODS}

\section{Reagents}

All protected natural amino acids, HCTU, 20\% piperidine in $\mathrm{DMF}$ and $0.4 \mathrm{M} \mathrm{N}$-methylmorpholine (NMM) in DMF were provided by Protein Technologies, Inc. (Tucson, AZ). Fmoc-Rink amide HMBA resin was purchased from Peptides International (Louisville, KY). Fmoc-Ala-Thr- $\Psi^{\mathrm{Me}, \mathrm{Me}}$ pro-OH, FmocSer-Ser- $\Psi^{\mathrm{Me}, \mathrm{Me}}$ pro-OH and Fmoc-Leu-Ser- $\Psi^{\mathrm{Me}, \mathrm{Me}}$ pro-OH were provided by Novabiochem (San Diego, CA), while Fmoc-DTrp-OH, Fmoc-D-Phe-OH and Fmoc-Ala-Wang PS resin were purchased from Novabiochem (San Diego, CA). Fmoc-AlaWang Chemmatrix resin was purchased from Matrix Innovation (Montreal, Canada). Solvents were purchased from VWR (West Chester, PA) and used without further purification. Anisole, ethanedithiol (EDT) and 1,8-diazabicyclo[5.4.0]undec7-ene (DBU) were purchased from Sigma-Aldrich (St. Louis, $\mathrm{MO}$ ), and trifluoroacetic acid (TFA) was purchased from Spectrum (Gardena, CA). Fmoc-Gly-Wang resin was purchased from Polymer Laboratories (Amherst, MA). HOCt was purchased from Lee BioSolutions, Inc. (St Louis, MO). 1, 1, 1,3,3,3Hexafluoroisopropan-2-ol (HFIP) was purchased from TCI America (Portland, OR).

\section{Peptide Synthesis}

65-74 ACP, G-LHRH, hAmylin ${ }_{1-37}$, oxytocin and GHRP-6 were synthesized on a Prelude peptide synthesizer at $40-\mu \mathrm{mol}$ scale using fivefold excess of Fmoc-amino acids (200 mM) relative to the Fmoc-Rink amide MBHA resin $(0.47 \mathrm{mmol} / \mathrm{g}$, for G-LHRH, hAmylin $_{1-37}$, oxytocin and GHRP-6) and Fmoc-Gly-Wang PS resin $\left(0.41 \mathrm{mmol} / \mathrm{g}\right.$ for $\left.{ }^{65-74} \mathrm{ACP}\right)$. Deprotection was performed using 20\% piperidine/DMF. Coupling was performed using $1: 1: 2$ amino acid/HCTU/NMM in DMF. DMF top washes (0.5 min) were performed between deprotection and coupling steps. Amino acids with D-configuration and pseudoproline dipeptides were delivered by the Prelude's Single-Shot feature, which gives a zero dead volume.

The $C$-peptide was synthesized on a Symphony peptide synthesizer at $25-\mu \mathrm{mol}$ scale using a six-fold excess of Fmoc-amino acid (112 mm) relative to the Fmoc-Gly-Wang resin $(0.41 \mathrm{mmol} / \mathrm{g})$. Deprotection was performed using $20 \%$ piperidine in DMF, and coupling was performed using $1: 0.9: 2$ amino acid/HCTU/DIPEA in DMF. DMF washes (0.5 min) were performed between deprotection and coupling steps.

$\beta$-Amyloid -42 $_{1-4}$ was synthesized on a Symphony peptide synthesizer at $25-\mu \mathrm{mol}$ scale using a ten-fold excess of Fmoc-amino acids $(200 \mathrm{~mm})$ relative to the Fmoc-Ala-WangPS resin $(0.25 \mathrm{mmol} / \mathrm{g})$. Deprotection was performed using DBU : Piperidine:DMF $(2: 20: 78)$. Coupling was performed using $1: 1: 4$ amino acid/HCTU/NMM in DMF. DMF washes (0.5 min) were performed between deprotection and coupling steps.

\section{Cleavage}

Cleavage was performed with 95:2:2:1 TFA/water/anisole/ EDT ( ${ }^{65-74}$ ACP, G-LHRH and GHRP-6), $95: 2.5: 2.5$ TFA/anisole/EDT (hAmylin ${ }_{1-37}$ ), $92.5: 2.5: 2.5: 2.5$ TFA/EDT/water/ TIS (oxytocin), $94: 1: 2.5: 2.5 \mathrm{TFA} / \mathrm{TIS} /$ water/EDT (C-peptide) and $94: 2: 2: 1: 1 \quad$ TFA/water/anisole/EDT/TIS ( $\beta$-amyloid $_{1-42}$ ).

\section{Peptide Analysis}

Crude peptides were analyzed on a Varian ProStar HPLC on a Microsorb-MW 300-5 C18 column, $250 \times 4.6 \mathrm{~mm}$. The gradients were (a) 5-65\% over $60 \mathrm{~min}$ for ${ }^{65-74} \mathrm{ACP}, \mathrm{G}-\mathrm{LHRH}$ and GHRP-6; (b) 5-95\% over 60 min for hAmylin ${ }_{1-37}$, oxytocin and $C$-peptide; and (c) 5-95\% over $60 \mathrm{~min}$ at $60^{\circ} \mathrm{C}$ with a Varian Pro Star column oven, model 510 for $\beta$-amyloid $1-42$. The solvent was aqueous MeCN with $0.1 \%$ TFA run at a flow rate of $1 \mathrm{ml} / \mathrm{min}$. Detection was at $214 \mathrm{~nm}$. Mass measurements were carried out on a Bruker Reflex III MALDITOF instrument using a matrix of sinapinic acid and reflectron acquisition in the positive mode.

\section{RESULTS AND DISCUSSION}

The seven peptides were chosen from peptides synthesized for instrument quality control purposes, customer applications or chemistry applications using HCTU as the coupling reagent. As a result, four of the seven peptides had been synthesized with PTI's standard test peptide protocol with $2.5 \mathrm{~min} \times 2$ deprotection times and $10 \mathrm{~min} \times 2$ acylation times. The remaining three peptides had used longer reaction times based on their application. We were able to reduce the reaction times for the shorter peptides (ten residues or less) to $1 \mathrm{~min}$ for deprotection and 2 min for coupling with no loss in crude peptide purity. In some cases, the crude purity actually improved at the reduced times. This is most likely due to the fact that short reaction times do not allow kinetically slower side reactions a chance to compete [2]. The reaction times for the longer peptides (over 30 residues) were reduced to $2-3$ minutes for deprotection and 5 min for coupling, resulting in crude peptides of equal or better purity. Cycle times were reduced from $37-131$ to $14-19 \mathrm{~min}$. Specific results for each peptide are detailed below. 


\section{Peptides Containing D-Amino Acids}

GHRP-6 (H-HwAWfK- $\mathrm{NH}_{2}$ ) is a hexapeptide containing two amino acids with D-configuration (D-Trp and DPhe) that has been shown to actively release growth hormone in vivo in humans and animals [14]. Initially, GHRP-6 was synthesized with $15 \mathrm{~min} \times 2$ deprotection times and $45 \mathrm{~min} \times 2$ acylation times to showcase the Single-Shot feature on the Prelude. GHRP-6 was then resynthesized with $0.5 \mathrm{~min} \times 2$ deprotection times and $1 \mathrm{~min} \times 2$ acylation times. This reduced the total synthesis time from 13.1 to $1.4 \mathrm{~h}$ without reducing crude peptide purity (Figure 1(a) and Table 1). In fact, a post-peak impurity in the longer synthesis was reduced with the shorter reaction times. The two peptides were analyzed on different HPLC systems, resulting in slightly different retention times. However, their identities were validated by mass spectrometry.

\section{The 65-74 Fragment of the Acyl Carrier Protein}

${ }^{65-74} \mathrm{ACP}$ is a well-known, difficult sequence used to test new synthesis protocols and used at Protein Technologies, Inc. for quality control purposes. ACP was first synthesized using our standard test peptide protocol in $5.6 \mathrm{~h}$, and then it was synthesized with reduced times in $2.1 \mathrm{~h}$ (Table 1). HPLC analysis of the crude peptides shows a significant pre-peak due to incomplete coupling of the valine (Figure 1(b)). However, we have shown that this pre-peak can be nearly eliminated by coupling the valine in $1: 1 \mathrm{DMF}: \mathrm{DMSO}$ for $5 \min \times 2$ [15].

\section{Oxytocin}

Oxytocin (H-CYIQNCPLG- $\mathrm{NH}_{2}$ ) is a component of the prohormone. It is located at its $N$-terminal end and contains a Cys- 1 to Cys-6 disulfide bridge. Linear oxytocin was initially synthesized with deprotection times of $3 \mathrm{~min}$ followed by $20 \mathrm{~min}$ and acylation times of $45 \mathrm{~min} \times 2$, resulting in a total synthesis time of $18.8 \mathrm{~h}$ (Table 1). This time was reduced to $2.1 \mathrm{~h}$, again with absolutely no loss in crude peptide purity (Figure 1(c)). As Figure 1(c) illustrates, HCTU did not generate racemization of the cysteine residues, even with long coupling times.

\section{Modified Luteinizing Hormone Releasing Hormone}

G-LHRH (H-GHWSYGLRPG- $\mathrm{NH}_{2}$ ) is another test peptide used for quality control of the Symphony and Prelude peptide synthesizers. G-LHRH was synthesized in $6.2 \mathrm{~h}$ using our standard test peptide protocol, then in $2.3 \mathrm{~h}$ with reduced times (Table 1). The crude purity was unchanged (Figures 1(d)).

\section{C-Peptide}

Chain A of the human proinsulin C-peptide [16] $(\mathrm{H}-$ EAEDLQVGQVELGGGPGAGSLQPLALEGSLG-OH) was initially synthesized using PTI's standard test peptide protocol resulting in a total synthesis time of $18.5 \mathrm{~h}$ (Table 1)(C-terminal $\mathrm{Q}$ is replaced with $\mathrm{G})$. The reaction times were then reduced to $1.5 \mathrm{~min} \times 2$ and $2 \mathrm{~min} \times 2$ for deprotection and acylation, respectively, halving

Table 1 Summary of deprotection and acylation of seven biologically active peptides in long and short reaction time

\begin{tabular}{|c|c|c|c|c|c|c|c|c|c|c|}
\hline & \multicolumn{4}{|c|}{ Long reaction time ${ }^{a}$} & \multicolumn{4}{|c|}{ Short reaction time } & \multicolumn{2}{|c|}{ Time reduction } \\
\hline & Deprotection $^{\mathrm{b}}$ & Acylation $^{\mathrm{c}}$ & $\begin{array}{l}\text { Cycle } \\
\text { Time }^{\mathrm{d}} \\
\text { (min) }\end{array}$ & $\begin{array}{l}\text { Synthesis } \\
\text { Time } \\
\text { (h) }\end{array}$ & Deprotection ${ }^{\mathrm{b}}$ & Acylation $^{\mathrm{c}}$ & $\begin{array}{l}\text { Cycle } \\
\text { Time }^{\mathrm{d}} \\
\text { (min) }\end{array}$ & $\begin{array}{l}\text { Synthesis } \\
\text { Time } \\
\text { (h) }\end{array}$ & $\begin{array}{l}\text { Cycle } \\
\text { time } \\
(\mathrm{min})\end{array}$ & $\begin{array}{l}\text { Synthesis } \\
\text { Timeg }^{\mathrm{g}} \\
\text { (h) }\end{array}$ \\
\hline GHRP-6 (6 Cycle) & $15 \min \times 2$ & $45 \min \times 2$ & 131 & 13.1 & $0.5 \min \times 2$ & $1 \min \times 2$ & 14 & 1.4 & 117 & 11.7 \\
\hline${ }^{65-74}$ ACP (9 Cycle) & $2.5 \min \times 2$ & $10 \min \times 2$ & 37 & 5.6 & $0.5 \min \times 2$ & $1 \min \times 2$ & 14 & 2.1 & 23 & 3.5 \\
\hline Oxytocin (9 Cycle) & 3 and $20 \mathrm{~min}$ & $45 \min \times 2$ & 125 & 18.8 & $0.5 \min \times 2$ & $1 \min \times 2$ & 14 & 2.1 & 111 & 16.7 \\
\hline G-LHRH (10 Cycle) & $2.5 \min \times 2$ & $10 \min \times 2$ & 37 & 6.2 & $0.5 \min \times 2$ & $1 \min \times 2$ & 14 & 2.3 & 23 & 3.9 \\
\hline$C$-Peptide (30 Cycle) & $2.5 \min \times 2$ & $10 \min \times 2$ & 37 & 18.5 & $1.5 \min \times 2$ & $2 \min \times 2$ & 18 & 9 & 19 & 9.5 \\
\hline $\begin{array}{l}\text { hAmylin 1-37 (34 } \\
\text { Cycle) }\end{array}$ & 3 and $20 \mathrm{~min}$ & $30 \min \times 2$ & 94 & 53.3 & $1 \min \times 2$ & $2.5 \min \times 2$ & 19 & 10.8 & 75 & 42.5 \\
\hline $\begin{array}{l}\beta \text {-Amyloid 1-42 (41 } \\
\text { Cycle) }\end{array}$ & $15 \min \times 1$ & $35 \min \times 1$ & $70^{\mathrm{h}}$ & 47.8 & $1 \min \times 2$ & $5 \min \times 1$ & 17 & 11.6 & 53 & 36.2 \\
\hline
\end{tabular}

\footnotetext{
a All seven peptides were synthesized at different times for our instrument quality assurance, an application note or a customer.

${ }^{\mathrm{b}}$ Fmoc protecting group was removed with $20 \%$ piperidine in DMF except $\beta$-amyloid - $_{1-42}(2: 20: 78$ DBU/Piperidine/DMF).

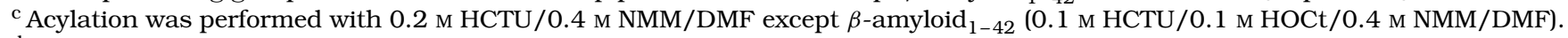

d Determined from Prelude with $0.5 \mathrm{~min} \times 6 \mathrm{DMF}$ top washes.

e Cycle time $\times$ number of cycles.

${ }^{\mathrm{f}}$ Long cycle time - short cycle time.

${ }^{g}$ Long synthesis time - short synthesis time.

${ }^{\mathrm{h}}$ Cycle time includes 5 min capping with $1: 1: 3$ Acetic anhydride/DIPEA/DMF.
} 
(a)

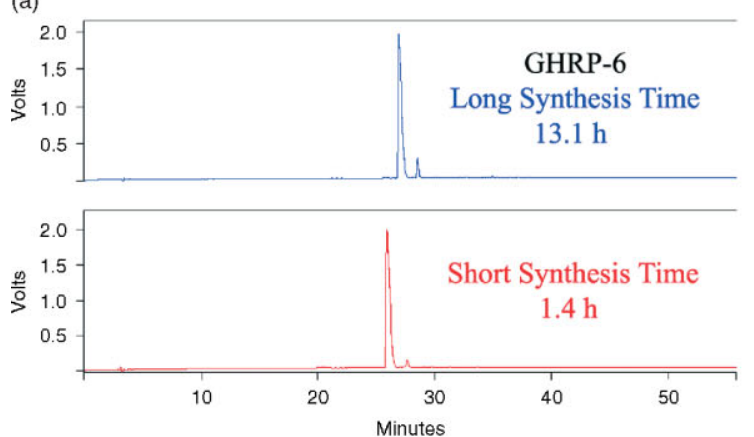

(c)
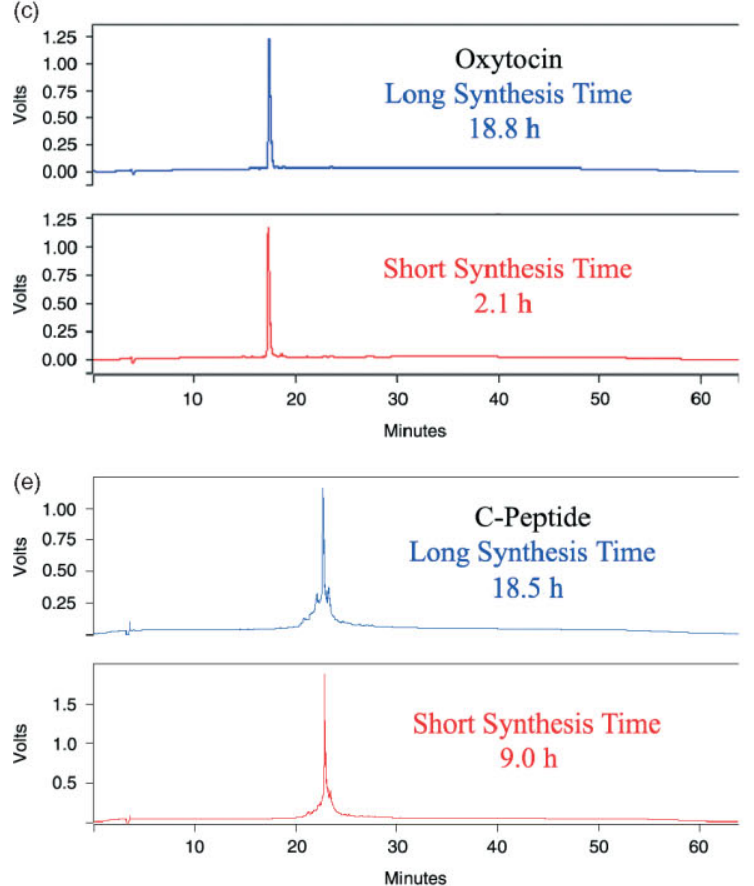

(b)

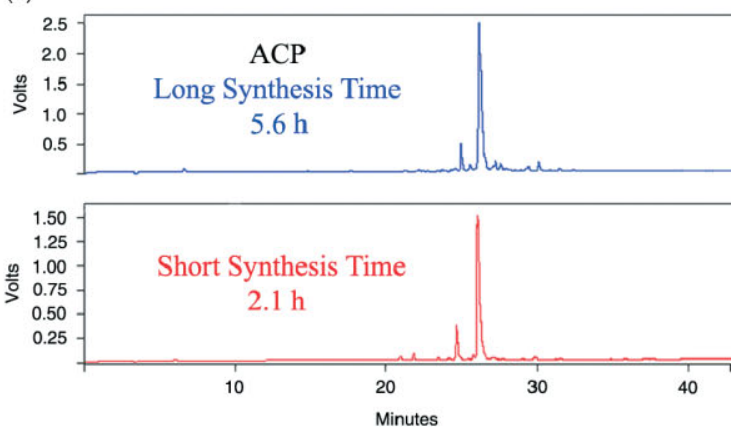

(d)
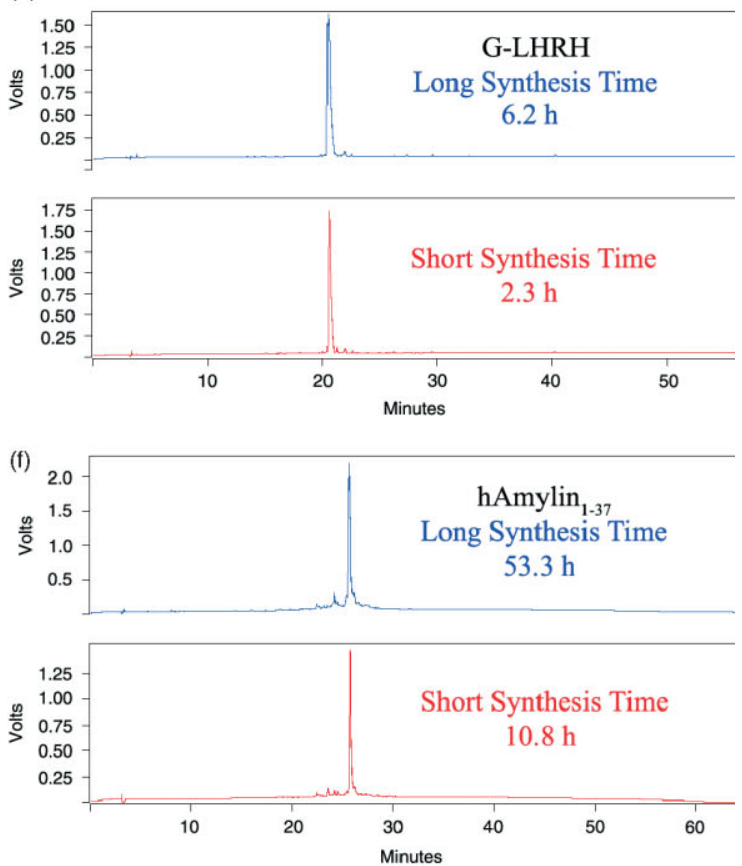
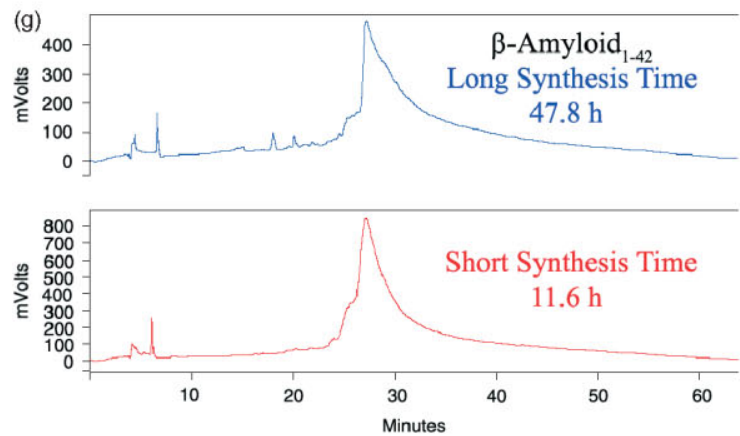

Figure 1 Crude HPLC comparison of (a) GHRP-6, (b) ${ }^{65-74}$ ACP, (c) oxytocin, (d) G-LHRH, (e) C-peptide (f) human amylin (1-37) and (g) human $\beta$-amyloid (1-42) in long and short reaction time.

the total synthesis time to $9 \mathrm{~h}$ (Table 1). The shorter reaction times produced a higher-purity crude peptide than the longer reaction times (Figure 1(e)).

\section{Human Amylin (1-37)}

Human amylin (1-37) (H-KCNTATCATQRLANFLVHSSNNFGAILSSTNVGSNTY- $\mathrm{NH}_{2}$ ) is a major component of the amyloid deposits found in the pancreases of type-II diabetes patients and contains a disulfide bridge between Cys-2 and Cys-7. Linear hAmylin ${ }_{1-37}$ was initially synthesized with deprotection times of $3 \mathrm{~min}$ followed by $20 \mathrm{~min}$, and acylation times of $30 \mathrm{~min} \times 2$, resulting in a total synthesis time of $53.3 \mathrm{~h}$. Pseudoproline dipeptides were incorporated into the sequence during the synthesis. Fmoc-AlaThr- $\Psi^{\mathrm{Me}, \mathrm{Me}}$ pro-OH was coupled in position $\mathrm{A}^{8} \mathrm{~T}$, FmocSer-Ser- $\Psi^{\mathrm{Me}, \mathrm{Me}}$ pro-OH was coupled at $\mathrm{S}^{19} \mathrm{~S}$ and FmocLeu-Ser- $\Psi^{\mathrm{Me}, \mathrm{Me}}$ pro-OH was coupled at position $\mathrm{L}^{27} \mathrm{~S}$. 
Deprotection times and coupling times were then reduced to $1.0 \mathrm{~min} \times 2$ and $2.5 \mathrm{~min} \times 2$, respectively, without any effect on the crude peptide purity (Figure 1(f)). In fact, a pre-peak impurity was reduced with the shorter reaction times. In addition, it was found that the pseudoproline dipeptides could be coupled in the same time as the natural amino acids. This reduced the total synthesis time to $10.8 \mathrm{~h}$ (Table 1) [17].

\section{$\beta$-Amyloid (1-42)}

Synthesis of the human $\beta$-amyloid $(1-42)$ peptide $(\mathrm{H}-$ DAEFRHDSGYEVHHQKLVFFAEDVGSNKGAIIGLMVGGVVIA-OH) by conventional SPPS has been reported to be difficult owing to the high hydrophobicity of the $C$-terminal segment and on-resin aggregation [18,19]. We initially synthesized $\beta$-amyloid - $_{1-42}$ with deprotection times of $15 \mathrm{~min} \times 1$, acylation times of $35 \mathrm{~min}$, and capping times of $5 \mathrm{~min}$ for a total synthesis time of $47.8 \mathrm{~h}$. $\beta$-Amyloid - $_{1-42}$ was then synthesized with $1 \mathrm{~min} \times 2$ deprotection $5 \mathrm{~min}$ acylation times, and $2.5 \mathrm{~min} \times 2$ capping times giving a total synthesis time of $14 \mathrm{~h}$ and produced a crude peptide with similar purity to the long synthesis. It was then found that removing the capping step from the shorter synthesis resulted in the same HPLC profile but with a total synthesis time of only $11.6 \mathrm{~h}$ (Figure $1(\mathrm{~g})$ ). The HPLC product peaks ( $\beta$-Amyloid $_{1-42}$ was dissolved in HFIP.) were slightly broadened as seen before with this peptide [20].

\section{CONCLUSION}

These results demonstrate that HCTU is a highly efficient coupling reagent that could be used as a low-cost alternative to more expensive, highly efficient reagents such as HATU when fast coupling times (5 min or less) are desired. Fast coupling times promote increased productivity, and in some cases may also result in purer crude peptides by not allowing kinetically slower side reactions to compete.

\section{REFERENCES}

1. Hetnarski B, Merrifield RB. Kinetics of coupling reactions in solid phase peptide synthesis. In Peptides 1987, Marshall GR (ed.). American Peptide Society: Leiden, 1988; 220-222.

2. Miranda LP, Alewood PF. Accelerated chemical synthesis of peptides and small proteins. Proc. Natl. Acad. Sci. U.S.A. 1999; 96: $1181-1186$.

3. Applied Biosystems. FastMoc ${ }^{\mathrm{TM}}$ Chemistry: HBTU Activation Chemistry in Peptide Synthesis on Model 430A, 1990.
4. Fields CG, Lloyd DH, Macdonald RL, Otteson KM, Noble RL. HBTU activation for automated Fmoc solid-phase peptide synthesis. Pept. Res. 1991; 4: 95-101.

5. Schnolzer M, Alewood P, Jones A, Alewood D, Kent SBH. In situ neutralization in Boc-chemistry solid phase peptide synthesis. Int. J. Pept. Protein Res. 1992; 40: 180-193.

6. Carpino LA. 1-Hydroxy-7-azabenzotriazole. An efficient peptide coupling additive. J. Am. Chem. Soc. 1993; 115: 4397-4398.

7. Alewood P, Alewood D, Miranda L, Love S, Meutermans W, Wilson D. Rapid in situ neutralization protocols for Boc and Fmoc solid-phase chemistries. Methods Enzymol. 1997; 289: 14-29.

8. Nokihara K, Nagawa Y, Hong S, Nakanishi H. Efficient solid-phase synthesis of a large peptide by a single coupling protocol with a single HPLC purification step. Lett. Pept. Sci. 1997; 4: 141-146.

9. Dalcol I, Rabanal F, Ludevid M, Albericio F, Giralt E. Convergent solid phase peptide synthesis: an efficient approach to the synthesis of highly repetitive protein domains. J. Org. Chem. 1995; 60: 7575-7581.

10. Marder O, Shvo Y, Albericio F. HCTU and TCTU: new coupling reagents: development and industrial aspects. Chim. Oggi 2002; 20: $37-41$

11. Sabatino G, Mulinacci B, Alcaro MC, Chelli M, Rovero P, Papini AM. Assessment of new 6-Cl-HOBt based coupling reagents for peptide synthesis. Part 1: coupling efficiency study. Lett. Pept. Sci. 2002; 9: 119-123.

12. Sabatino G, Alcaro MC, Pozo-Carrero MDL, Chelli M, Rovero P, Papini AM. Assessment of 6Cl-HOBt based coupling reagents in solid-phase cyclopeptide synthesis. In Peptides 2003, Chorev M, Sawyer TK (eds.). American Peptide Society: Massachusetts, 2004; 49-50.

13. Peptide International. 2007-2008; Catalog, 66-67.

14. Muccioli G, Tschop M, Papotti M, Deghenghi R, Heiman M, Ghigo E. Neuroendocrine and peripheral activities of ghrelin: implications in metabolism and obesity. Eur. J. Pharmacol. 2002; 440: $235-254$.

15. Fuentes G, Hood C, Page K, Patel H, Park JH, Menakuru M. Fast Conventional Synthesis of ${ }^{65-74} A C P$ on the Symphony ${ }^{\circledR}$ and Prelude $^{\mathrm{TM}}$ European Peptide Symposium, 2007; http://www.ptiinstruments.com/images/29EPS_P559.pdf [last accessed June 2007].

16. Heath WF, Belagaje RM, Brooke GS, Chankce RE, Hoffmann JA, Long HB, Reams SG, Roundtree C, Shaw WN, Slieker LJ, Sundell KL, Dimarchi RD. (A-C-B) human proinsulin, a novel insulin agonist and intermediate in the synthesis of biosynthetic human insulin. J. Biol. Chem. 1992; 267: 419-425.

17. Page K, Hood CA, Patel H, Fuentes G, Menakuru M, Park JH. Fast Fmoc synthesis of hAmylin ${ }_{1-37}$ with pseudoproline assisted onresin disulfide formation. J. Pept. Sci. 2007 (in press). DOI: 10.1002/psc.909.

18. Quibell M, Turnell WG, Johnson T. Preparation and purification of $\beta$-amyloid (1-43) via soluble, amide backbone protected intermediates. J. Org. Chem. 1994; 59: 1745-1750.

19. Tickler A, Clippingdale AB, Wade JD. Amyloid- $\beta$ as a "difficult sequence" in solid phase peptide synthesis. Protein Pept. Lett. 2004; 11: $377-384$.

20. Burdik D, Soreghan B, Kwon M, Kosmoksi J, Knauer M, Henschen A, Yates J, Cotman C, Glabe C Assembly and aggregation properties of synthetic Alzheimer's A4/beta amyloid peptide analogs. J. Biol. Chem. 1992; 267: 546-554. 